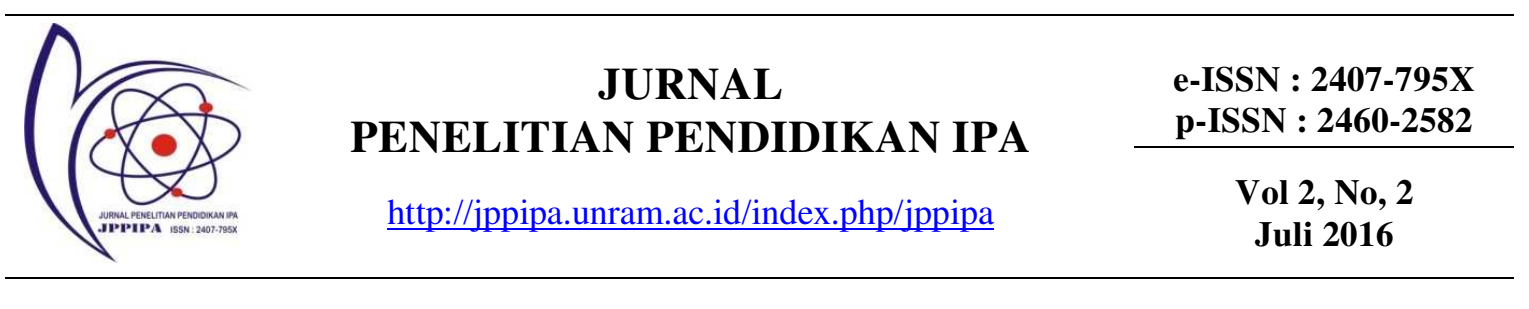

\title{
PENGEMBANGAN LEMBAR KEGIATAN SISWA (LKS) MODEL LEARNING CYCLE 5E
}

Muhamad Zikrullah $^{1}$, Wildan ${ }^{2}$, Yayuk Andayani ${ }^{3}$

Program Studi Pendidikan IPA Program Pascasarjana Universitas Mataram ${ }^{123}$

Email: yayukmtr@gmail.com

\begin{tabular}{|c|c|}
\hline Key Words & Abstract \\
\hline Student's & The aims of this study were to generate 5E learning cycle model student's work \\
\hline Work Sheet, & sheet wich suitable to be implemented on subject matter of the reduce-oxidace \\
\hline $5 E$ & rections at class $X$. The method used in this study was according to the model of \\
\hline Learning & 4D development were Define, Design, Develop, and Disseminate. The results of \\
\hline Cycle & limited testing by 6 students and 2 teacher's chemistry of MAN 1 Mataram and \\
\hline Model & $\begin{array}{l}\text { results of the expert validation by } 3 \text { validators showed that } 5 E \text { learning cycle } \\
\text { model student's work sheet was very suitable to be used with scores } 3,36,3,37 \text {, } \\
\text { dan } 3,33 \text { on scale } 1-4\end{array}$ \\
\hline Kata Kunci & Abstrak \\
\hline Lembar & Tujuan dari penelitian adalah untuk menghasilkan Lembar Kegiatan Siswa (LKS) \\
\hline Kegiatan & Model 5E yang layak digunakan dan dapat meningkatkan prestasi belajar siswa \\
\hline Siswa, & pada materi pokok reaksi reduksi-oksidasi mata pelajaran kimia kelas X. Model \\
\hline Model & pengembangan yang digunakan dalam penelitian ini mengikuti langkah-langkah \\
\hline Learning & model pengembangan four D yaitu: Define, Design, Develop, dan Disseminate. \\
\hline Cycle 5E & $\begin{array}{l}\text { Hasil uji terbatas oleh } 6 \text { orang siswa dan } 2 \text { orang guru kimia MAN } 1 \text { Mataram dan } \\
\text { uji validasi oleh } 3 \text { orang validator menunjukkan bahwa lembar kegiatan siswa } \\
\text { (LKS) model learning cycle 5E sangat layak digunakan dengan skor masing- } \\
\text { masing } 3,36,3,37 \text {, dan } 3,33 \text { pada rentang skor } 1-4\end{array}$ \\
\hline
\end{tabular}




\section{PENDAHULUAN}

Salah satu jenis bahan ajar yang sering digunakan oleh setiap sekolah adalah Lembar Kegiatan Siswa (LKS). Saat ini, dalam realitas pendidikan di lapangan, masih banyak digunakan di sekolah-sekolah berupa Lembar Kegiatan Siswa (LKS) yang diperoleh dari penerbit yang sifatnya instant tanpa ada upaya merencanakan, menyiapkan, dan menyusun sendiri (Purwanto, dkk, 2012). Penyusunan Lembar Kegiatan Siswa (LKS) membantu siswa dalam menginterpretasi atau memaknai dan menjelaskan objek dan peristiwa yang dipelajari (Purwanto, dkk, 2012).

Hasil studi pendahuluan terhadap Lembar Kegiatan Siswa (LKS) di MAN 1 Mataram diperoleh informasi antara lain: (1) Bahan ajar berupa Lembar Kegiatan Siswa (LKS) yang digunakan bukan hasil pengembangan dari guru sekolah tersebut akan tetapi Lembar Kegiatan Siswa (LKS) yang diperoleh dari penerbit yang telah disediakan sehingga terkadang tidak sesuai dengan kebutuhan dan kondisi siswa. (2) Lembar kegiatan siswa (LKS) yang digunakan belum menyentuh keterkaitan antara materi terutama materi redoks dengan konteks dalam kehidupan sehari-hari siswa, hal yang demikian membuat siswa merasa kurang tertarik mengikuti proses pembelajaran. (3) Petunjuk praktikum materi reaksi redoks pada Lembar Kegiatan Siswa (LKS) memuat langkah-langkah yang sulit untuk dilakukan oleh siswa, sehingga guru jarang memberikan metode praktikum pada materi reaksi redoks, (4) Petunjuk pada Lembar Kegiatan Siswa (LKS) kurang mampu mengarahkan siswa untuk aktif dalam kegiatan diskusi kelas maupun diskusi kelompok serta memfasilitasi siswa supaya aktif belajar secara mandiri di luar jam sekolah, Yamin dalam Oka (2010) menjelaskan bahwa kegiatan belajar mandiri memiliki pengaruh yang signifikan terhadap peningkatan prestasi belajar siswa, (5) Soal-soal latihan dan penugasan yang ada dalam Lembar Kegiatan Siswa (LKS) yang digunakan secara umum pada materi redoks kurang beragam sehingga siswa kurang terlatih untuk menyelesaikan permasalahanpermasalahan yang lebih kompleks.

Salah satu upaya yang sedang dilakukan pemerintah dalam meningkatkan mutu proses pembelajaran adalah pembelajaran yang berpusat pada siswa (student centered) melalui kegiatan inkuiri (Permendiknas, 
2013). Salah satu model dengan kegiatan inkuiri adalah model siklus belajar (learning cycle) 5 tahap (Bass, et al, 2009). Model siklus belajar (learning cycle) 5 tahap merupakan rangkaian tahap-tahap kegiatan yang diorganisasi sedemikian rupa sehingga siswa dapat menguasai kompetensi-kompetensi yang harus dicapai dalam pembelajaran dengan jalan berperan aktif (Bass, et. al). Model ini berawal dari model tiga tahap, yaitu: Exploration, invention, dan discovery. Tiga tahap tersebut saat ini dikembangkan menjadi lima tahap yaitu: engage, explore, explain, elaborate, dan evaluate (Hanuscin \& Lee, 2008). Model pembelajaran learning cycle (siklus belajar) $5 \mathrm{E}$ ini dipilih karena memberikan kesempatan yang lebih luas kepada siswa untuk membangun konsep dari materi yang dipelajari kemudian menggunakan konsep tersebut untuk memecahkan masalah yang lebih kompleks. Siswa lebih dilibatkan secara aktif dalam proses pembelajaran, meningkatkan

\section{METODE}

Jenis penelitian yang digunakan dalam penelitian ini merupakan penelitian pengembangan $(R \& D)$. Model pengembangan yang digunakan dalam penelitian ini mengadopsi empat motivasi belajar dan pembelajaran menjadi lebih bermakna (Bass, et al, 2009). Dasna (2005) menyatakan bahwa dalam model siklus belajar 5E siswa mengembangkan pemahamannya terhadap suatu konsep dengan kegiatan mencoba (hand-on activities) sebelum diperkenalkan dengan kata-kata melalui diskusi sehingga proses pembelajaran menjadi lebih bermakna.

Lembar Kegiatan Siswa (LKS) yang sesuai dengan kebutuhan siswa, berorientasi pada kompetensi dasar, melatih siswa untuk aktif dan mandiri, memudahkan siswa untuk memahamai materi yang diberikan, ringkas dan kaya akan tugas untuk berlatih, serta layak digunakan adalah salah satu hal yang perlu diusahakan. Berdasarkan uraian tersebut, tujuan dari penelitian ini adalah untuk menghasilkan lembar kegiatan siswa (LKS) model learning cycle 5E yang layak digunakan pada pembelajaran kimia materi pokok reaksi reduksi-oksidasi.

tahap pengembangan yang dikembangkan oleh Sivasailam Thiagarajan. (1974). Model pengembangan ini meliputi tahap Define (pendefinisian), tahap Design (perancangan), tahap Develop 
(pengembangan), tahap Disseminate (penyebarluasan). Pada tahap Define dilakukan studi pendahuluan yang meliputi analisis kebutuhan, analisis siswa, analisis materi, analisis tugas dan analisis tujuan pengembangan. Tahap Design dilakukan untuk menentukan media dan format penyusunan Lembar Kegiatan Siswa (LKS) berdasarkan prosedur yang telah distandarkan. Tahap Develop diawali kegiatan menyusun prototype (draft I) berdasarkan hasil yang diperoleh pada tahap define dan design. Draft I yang disusun dikonsultasikan untuk memperoleh masukan dan saran. Masukan dan saran yang telah diperoleh menjadi bahan perbaikan draft I untuk menghasilkan draft II. Draft II diuji kelayakannya berdasarkan aspek penyajian isi, bahasa dan kesesuaian isi melalui uji validasi ahli oleh 3 orang validator sebelum diuji cobakan pada uji coba terbatas. Masukan dan saran dari validator menjadi bahan perbaikan draft II untuk menghasilkan draft III. Draft III diuji kelayakannya berdasarkan aspek bahasa/keterbacaan dan penyajian isi/kemenarikan oleh 2 orang guru kimia dan 6 orang siswa XI IPA (2 orang siswa berkemampuan tinggi, 2 orang siswa berkemampuan sedang, 2 orang siswa berkemampuan rendah). Masukan dan saran dari uji coba terbatas menjadi bahan perbaikan draft III untuk menghasilkan produk akhir. Proses Disseminate (penyebarluasan) dilakukan melalui pembuatan artikel hasil penelitian yang dipublikasikan kedalam jurnal.

$\begin{array}{ccr}\text { Data } & \text { yang } & \text { dikumpulkan } \\ \text { berdasarkan } & \text { penilaian } & \text { kelayakan }\end{array}$
Lembar Kegiatan Siswa (LKS) Model Learning Cycle 5E mencangkup empat kategori, skor 4 untuk kategori sangat layak, skor 3 untuk kategori layak, skor 2 untuk kategori kurang layak dan kategori 1 untuk kategori tidak layak. Selanjutnya, data penilaian kelayakan Lembar Kegiatan Siswa (LKS) Model Learning Cycle 5E dianalisis dengan langkah-langkah sebagai berikut:

a. Tabulasi semua data yang diperoleh dari para pakar validator, guru, dan siswa untuk setiap aspek dari skor penilaian yang tersedia dalam instrumen penilaian.

b. Menghitung skor total rata-rata dari setiap aspek

c. Mengubah skor rata-rata menjadi nilai dengan kriteria

Agar dapat mengetahui kualitas perangkat pembelajaran hasil pengembangan maka data yang mula- 
mula berupa skor, diubah menjadi data kualitatif (data interval) dengan skala empat (4). Adapun acuan pengubahan skor menjadi skala empat (4) tersebut menurut Widoyoko (2012) sesuai pada Tabel 1.1.

Tabel 1.1 Kriteria Nilai Rerata Total Skor

\begin{tabular}{lcl}
\hline Nilai & Interval skor & Kategori \\
\hline $\mathrm{A}$ & $3,26-4,00$ & Sangat layak \\
$\mathrm{B}$ & $2,51-3,25$ & Layak \\
$\mathrm{C}$ & $1,76-2,50$ & Kurang Layak \\
$\mathrm{D}$ & $1,00-1,75$ & Tidak Layak \\
\hline
\end{tabular}

Adapun tahap-tahap pengembangan yang peneliti tempuh pada penelitian pengembangan ini dapat dijelaskan menggunakan Gambar 1.1 (Thiagarajan et al, 1974)

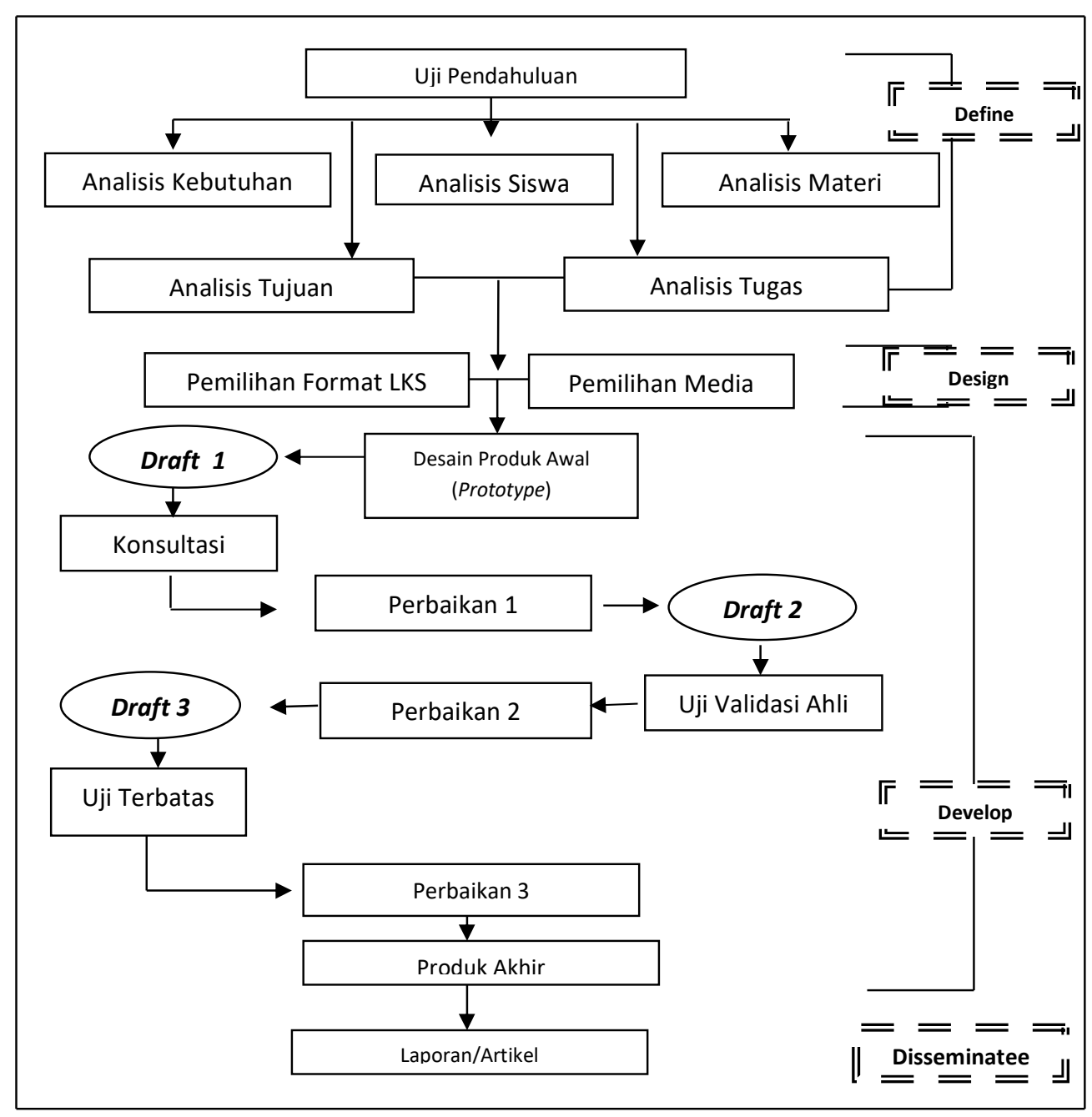

Gambar 1.1. Diagram Alur Rancangan Pengembangan 4D vang Dimodifikasi 


\section{HASIL DAN PEMBAHASAN}

Hasil studi pendahuluan pada tahap difine (pendefinisian) berupa analisis kebutuhan terhadap Lembar Kegiatan Siswa (LKS) Model Learning Cycle 5E pada pembelajaran kimia materi pokok reaksi reduksi-oksidasi dilanjutkan untuk menentukan format penulisan Lembar Kegiatan Siswa (LKS) sehingga diperoleh draft I. Selanjutnya draft I dikonsultasikan pada tahap develop (pengembangan) untuk memperoleh masukan dan saran sebagai bahan perbaikan untuk menghasilkan draft II. Selanjutnya dilakukan uji Tabel 1.2 Hasil uji validasi ahli validasi ahli untuk menguji kesesuain isi, kebahasaan dan penyajian oleh 3 orang validator terhadap draft II.

Kualitas bahan ajar dapat diukur dengan kualitas kevalidan, keefektifan, dan kepraktisan jika digunakan dalam pembelajaran (Aji Nugraha, 2013). Berdasarkan instrumen penilaian yang digunakan untuk mengumpulkan data berupa tanggapan ahli mengenai draft II tersebut, para ahli memberikan tanggapan yang positif terhadap pengembangan Lembar Kegiatan Siswa (LKS) Model Learning Cycle 5E dengan hasil seperti pada Tabel 1.2

\begin{tabular}{clc}
\hline No & \multicolumn{1}{c}{ Aspek yang dinilai } & Rata-rata \\
\hline 1 & Kesesuaian isi & 3.33 \\
2 & Bahasaan & 3.33 \\
3 & Penyajian & 3.33 \\
\hline & Rata-rata & 3.33 \\
\hline & Kategori & Sangat Layak \\
\hline
\end{tabular}

Saran dan masukan dari validator terhadap draft II dijadikan bahan perbaikan untuk menghasilkan draft III. Uji coba terbatas oleh 6 orang siswa kelas XI IPA dan 2 orang guru kimia MAN 1 Mataram untuk menguji bahasa/keterbacaan dan penyajian isi/kemenarikan. Berdasarkan instrumen penilaian yang digunakan untuk mengumpulkan data berupa tanggapan guru mengenai draft III tersebut melalui uji terbatas, para guru memberikan tanggapan seperti pada Tabel 1.3. 
Tabel 1.3 Hasil uji terbatas oleh guru

\begin{tabular}{clc}
\hline No & \multicolumn{1}{c}{ Aspek yang dinilai } & Rata-rata \\
\hline 1 & Kesesuaian isi & 3.62 \\
\hline 2 & Bahasa & 3.00 \\
\hline 3 & Penyajian & 3.50 \\
\hline \multicolumn{2}{r}{ Rata-rata } & 3.37 \\
\hline & Kategori & Sangat Layak \\
\hline
\end{tabular}

Berdasarkan instrumen penilaian draft III tersebut uji terbatas, para siswa yang digunakan untuk mengumpulkan memberikan tanggapan seperti pada data berupa tanggapan siswa mengenai Tabel 1.4.

Tabel 1.4 Hasil uji terbatas oleh siswa

\begin{tabular}{cccc}
\hline No & & Aspek yang dinilai & Rata-rata \\
\hline 1 & Penyajian & & 3.36 \\
\hline 2 & Bahasa & & 3.36 \\
\hline & Rata-rata & 3.36 \\
\hline & & Kategori & Sangat layak \\
\hline
\end{tabular}

Hasil uji terbatas terhadap draft III oleh 2 orang guru kimia dan 6 orang siswa MAN 1 Mataram merupakan acuan dalam menyusun hasil akhir. Sehingga diperoleh hasil akhir berupa Lembar Kegiatan Siswa (LKS) Model Learning Cycle 5E.

Data yang kualitatif berupa masukan/saran dalam rangka perbaikan Lembar Kegiatan Siswa (LKS) Model Learning Cycle 5E pada uji ahli dan uji

Hasil penelitian oleh Sari (2013) dan Nurina (2012) menunjukan bahwa hasil pengembangan LKS model siklus belajar 5E memiliki kategori baik dan layak. Indriyani (2013) menunjukan bahwa LKS ditinjau dari aspek terbatas beberapa diantaranya adalah sebagai berikut: (1) Ukuran hurufnya lebih baik diperkecil karena terlalu besar, (2) Warna dan gambar kurang serasi, (3) Beberapa kata tidak sesuai dengan EYD (tidak baku), (4) Menggunakan gambar yang lebih menarik dan faktual, dan 5) Halaman sampul didesain lebih menarik, dan 6) Gunakan ukuran huruf standar (times new roman)

kelayakan isi, aspek kebahasaan, aspek penyajian, dan aspek kegrafikan secara keseluruhan baik dan layak digunakan.

Ufuk (2013) mengemukakan bahwa pelaksanaan pembelajaran menggunakan bahan ajar hendaknya 
dilaksanakan dilaksanakan dalam model pembelajaran kooperatif konstruktivistik. Ruang diskusi dalam pembelajaran akan mengarahkan siswa dalam menemukan konsep. Hal tersebut di atas terangkum dalam suatu bahan ajar berupa lembar kegiatan siswa (LKS) yang diintegrasikan dengan kegiatan pembelajaran model siklus belajar 5E. Lembar Kegiatan Siswa (LKS) Model Learning Cycle 5E adalah panduan bagi siswa untuk melakukan penyelidikan atau pemecahan masalah, diintegrasikan dengan tahapan model pembelajaran 5E yang merangkum metode-metode pembelajaran yang telah disebutkan diatas, seperti metode demonstrasi pada tahapan Engage, kooperatif pada tahapan Explain dan diskusi serta berisi langkah-langkah kerja bagi siswa dalam setiap pembelajaran sehingga siswa dapat mempelajari konsep berdasarkan hakikat pembelajaran konstruktivisme. Fase Engage mempersiapkan kesiapan mental siswa sebelum pembelajaran dan sikap siswa dalam pembelajaran berpengaruh terhadap prestasi belajar siswa (Moore, J.C dan Rubbo, 2011). Trianto (2010) menjelaskan bahwa LKS dapat memuat sekumpulan kegiatan mendasar yang harus dilakukan oleh siswa untuk memaksimalkan pemahaman dalam upaya pembentukan kemampuan dasar sesuai dengan indikator pencapaian hasil belajar yang harus ditempuh.

Karakteristik khas yang dimiliki oleh Lembar Kegiatan Siswa (LKS) Learning Cycle 5E terdiri dari Petunjuk Kegiatan Siswa (PKS) yang dirancang mengikuti tahapan model learning cycle 5E untuk memfasilitasi siswa melakukan kegiatan pembelajaran yang lebih kontekstual. Bagian petunjuk kegiatan siswa (PKS) meliputi tahapan model learning cycle 5E (engage, explore, explain, elaborate, \& evaluate) dan di setiap tahap siswa dibimbing bagaimana cara membangun suatu konsep berdasarkan filosofi konstruktivisme (Mann \& Treagust, 2010) Pada tahap Engage, siswa diberikan pertanyaan pengarah yang berhubungan dengan reaksi reduksioksidasi, pertanyaan ini bertujuan untuk menginvestigasi konsep awal siswa, memancing rasa keingintahuan siswa terhadap materi reaksi reduksioksisidasi. Kesiapan siswa dalam menerima pelajaran sangat berperan penting dalam pembelajaran (Bell \& Linn, 2007) dan Ayas (1997). Tahap Explore, siswa melakukan kegiatan 
penyelidikan berupa eksperimen sederhana untuk memperoleh data-data. Tahapan ini berperan terhadap pembentukan keterampilan proses sains siswa (Fethiye, 2011). Tahap Explain, siswa melakukan diskusi untuk menganalisis hasil pengamatan dan menjawab bahan diskusi berupa soalsoal penguasan konsep, kemudian mengkomunikasikan hasil kegiatan belajar melalui kegiatan presentasi kelompok. Tahap Elaborate, memperluas pemahaman konseptual dan keterampilan-keterampilan siswa melalui kegiatan menanya untuk menggali pengalaman-pengalaman belajar yang baru dan membangun pemahaman yang lebih dalam dan luas serta mengaplikasikan pemahaman tersebut. Tahap Evaluate, mengevaluasi kemajuan siswa dalam mencapai tujuantujuan pembelajaran yang telah ditetapkan melalui kegiatan menyimpulkan dan menyajikan hasil pengamatan dalam bentuk laporan tertulis.

Lembar Hasil Kegiatan Siswa (LHKS) merupakan lembaran yang disiapkan untuk menulis hasil kegiatan pembelajaran baik berupa pengamatan, percobaan dan diskusi yang dilakukan siswa. Pengembangan LHKS mengikuti
PKS, karena LHKS merupakan lembar kerja untuk menulis hasil pengamatan dan bahan diskusi berdasarkan petunjuk yang ada dalam PKS. Lembar Hasil Kegiatan Siswa (LHKS) dimaksudkan untuk membantu siswa dalam menulis dan menyusun kembali hasil kegiatan pembelajaran berdasarkan PKS sehingga diperoleh suatu konsep yang matang untuk dipresentasikan.

Arsyad (2004) mengatakan bahwa sesuatu hal baru jarang sekali dapat dipelajari secara efektif hanya dengan sekali jalan. Agar suatu pengetahuan dan keterampilan dapat menjadi bagian kompetensi atau kecakapan intelektual seseorang, haruslah pengetahuan atau keterampilan itu sering diulangi dan dilatih dalam berbagai konteks. Sehingga tahap Eksplore, Ekplain, Elaborasi, dan Evaluasi pada lembar kegiatan siswa (LKS) model learning cycle 5E dapat memfasilitasi siswa untuk melatih pengetahuan siswa dalam berbagai permasalahan dan konteks.

\section{KESIMPULAN}

Berdasarkan penelitian pengembangan yang telah dilakukan dapat disimpulkan bahwa Lembar Kegiatan Siswa (LKS) Model Learning Cycle 5E layak 
digunakan pada pembelajaran kimia materi pokok reaksi reduksi-okisidasi.

\section{DAFTAR PUSTAKA}

Aji Nugraha D., et al. (2013). Pengembangan Bahan Ajar Reaksi Redoks Bervisi SETS. Berorientasi kontsruktivistik. Journal of Innonative Science Education (JISE) Vol. 2 No.1. Diakses tanggal 03-11-2015.

Arsyad, Azhar. 2004. Media Pembelajaran. Jakarta: PT Raja Grafindo Persada.

Ayas, A., \& Demirbaş, A. (1997). Turkish secondary students' conception of introductory chemistry concepts. International Journal of Chemical Education, 74(5), 518-521.

Bass, J. E Contat, T.L. and Carin, A. A. 2009. Teaching Science as Inquiry. Boston: Pearson.

Bell, P., \& Linn, M. C., 2007. Designning for Learning from the web with KIE. International Journal of Science Education.

Dasna, I.W. 2005. Model Siklus Belajar (Learning Cycle) Kajian Teoritis dan Impelementasinya dalam Pembelajaran Kimia. Malang: Universitas Negeri Malang.

Fethiye Karsli. 2011. Develoving A Laboratory Activity On Electrochemical Cell by Using $5 E$ Learning Model For Teaching and Improving Science Process Skills. International
Journal of Educatian Science. ISSN: 1308-8971

Hanuscin, D.L. \& Lee, M. C. 2008.Using a Learning Cycle Approach to Teaching the Learning Cycle to Preservice Elementary Teachers. International Journal of Elementary Science Educatio, Vol. 20, No. 2. Western Illinois University.

Indriani, IR. 2013. Pengembangan LKS Fisika Berbasis Siklus Belajar (Learning Cycle) untuk Meningkatkan Prestasi Belajar dan Mengembangkan Kemampuan Berpikir Kritis pada Siswa SMA Kelas X Pokok Bahasan Elektromagnetik. Tesis tidak diterbitkan. Yogyakarta.Pendidikan Fisika Program Pasca Sarjana Universitas Ahmad Dahlan.

Mann, M. \& Treagust, F.D (2010). Students's conception about energy and the human body. Science Education International, 21 (3), 144-159

Moore, J.C dan Rubbo, L. J. 2011. Scientifik Reasoning Abilities of Non-Science Major in PhysicsBased Course. Aps Journal. Volume 8, Issue 1

Nurina, dkk. 2012. Pengembangan Lembar Kegiatan Siswa (LKS) dengan Model Siklus Belajar 5 E Berbasis Konstruktivistik pada Materi Sistem Sirkulasi Manusia untuk Kelas XI. Jurnal Universitas Negeri Malang.

Oka, AA. 2010. Pengaruh Penerepan Belajar Mandiri pada Materi Ekosistem Terhadap 
Keterampilan Berpikir Kritis dan Kemampuan Memecahkan Masalah Siswa SMA di Kota Metro. Artikel Pendidikan Biologi Universitas Muhammadiyah Metro Lampung.

Permendiknas RI Nomor 65 Tahun 2013 tentang Standar Proses.

Purwanto, dkk. 2012. Pengembangan Modul. Jakarta: Depdiknas.

Sari.,S.I. 2013. Pengembangan Lembar Kegiatan Siswa Berorientasi Model Learning Cycle 5E pada Materi Ekosistem. Jurnal Unesa BioEdu, Vol. 2/No. 1/Januari.

Thiagarajan, S., Semmel, DS., Semmel, MI. $\quad 1974 . \quad$ Instruction Development for Training Teacher of Exeptional Children: A Sourcebook. Indiana University Bloomington. Diunduh dari: http://files.eric.ed.gov./fulltext/E D090725.pdf. Tanggal: 16 Februari 2015.

Trianto. 2010. Model Pembelajaran Terpadu. Jakarta: Bumi Aksara.

Ufuk Toman. 2013. Extended Worksheet Developed According to $5 E$ Model Based on Constructivist Learning Approach . International Journal on New Trends in Education and Their Implications October 2013 Volume: 4 Issue: 4 Article: 16 ISSN 1309-6249. Diakses tanggal 11-01-2016. 